УдК 616.31-089.444

DOI 10.11603/2411-1597.2020.1.11031

\title{
ПРАВА ЛЮДИНИ У СФЕРІ ПАЛІАТИВНОЇ ДОПОМОГИ
}

\author{
Г. В. Савка \\ Тернопільський національний медичний університет \\ імені І. Я. Горбачевського МОз України
}

У статті проаналізовано основні положення, пов’язані з правами людини в сфері паліативної допомоги. Паліативна допомога як окремий вид медичної допомоги закріплена законодавчо 32011 р. Цей вид допомоги входить у програму медичних гарантій і вже нині реалізується на рівні первинної допомоги.

\section{HUMAN RIGHTS IN THE AREA OF PALLIATIVE CARE}

\section{H. V. Savka}

\section{Horbachevsky Ternopil National Medical University}

The article analyzes the main human rights provisions in palliative care. Palliative care as a separate type of medical care has been enshrined by legislation since 2011. This kind of care consists in the medical guarantee program and is already actually used at the primary care level.

Вступ. Право на індивідуальний підхід до лікування покладено в основу трансформації системи охорони здоров'я, кінцева мета якої - поставити в центр уваги пацієнта і його здоров'я. Навіть у найтяжчих випадках зусилля медиків мають бути спрямовані на полегшення стану пацієнта, попередження, за можливості, його страждань і болю.

Паліативна допомога входить в «зелений перелік» послуг, гарантованих державою кожному громадянину України.

Попередження страждань і болю має бути одним із ключових завдань у тих випадках, коли медицина не може допомогти пацієнту одужати. На останніх стадіях перебігу невиліковних захворювань пацієнти отримують паліативну допомогу: комплекс заходів, спрямованих на полегшення фізичних й емоційних страждань пацієнта та надання психосоціальної і моральної підтримки членам їхніх сімей.

Паліативна допомога як окремий вид медичної допомоги закріплена законодавчо з 2011 р. Цей вид допомоги входить у програму медичних гарантій і вже нині реалізується на рівні первинної допомоги.

На законодавчому рівні урегульовано питання призначення знеболювальних препаратів тяжкохворим пацієнтам. Наразі скасовано низку положень, через які пацієнти не могли отримати знеболювання. Тепер процедура є простішою як для пацієнтів і їхніх родичів, так і для лікарів.

Нині тяжкохворі пацієнти можуть отримати безоплатне лікування в хоспісах.

Права пацієнта на вибір методів лікування та інформовану згоду на медичне втручання належать до фундаментальних прав людини. Сучасна європейська доктрина інформованої згоди пацієнта, до якої прагне долучитися й Україна, основана на принципі поваги до гідності людини, її прав на самовизначення, на самостійне прийняття рішень із важливих питань стосовно життя та здоров'я.

У європейській юрисдикції «свобода погодитись чи відмовитись від конкретного методу лікування або обрати альтернативний метод лікування має першорядне значення для принципів самовизначення й особистої автономії людини» [1].

В Україні добровільна інформована згода пацієнта також $є$ умовою правомірності проведення будь-якого медичного втручання. Принцип інформованої згоди знайшов відображення, зокрема у ст. 28 Конституції України. Права пацієнтів в Україні на вибір лікувального закладу, лікаря, методів лікування, а також на відмову від лікування закріплено у ст. 284 ЦК України, ст. 43 Закону України «Основи законодавства України з охорони здоров'я».

(c) Г. В. Савка, 2020 
Існує велика потреба в паліативній допомозі в усьому світі. 358 млн людей, які помирають щороку, щонайменше $60 \% \in$ невиліковно хворими і потребують паліативної допомоги. Паліативна допомога могла 6 поліпшити якість життя 80 \% людям, які страждають від невиліковних хвороб, за умови зменшення болю і страждань в останні дні життя.

На жаль, для багатьох програми паліативної допомоги або недоступні, або недосяжні. Спеціальний доповідач ООН із питань охорони здоров'я відзначив, що «пацієнти страждають від сильного і помірного болю там, де паліативна допомога по суті відсутня, і вони воліли 6 померти, ніж продовжувати жити 3 сильними болями, які не підлягають лікуванню» [2].

Паліативна допомога має бути доступна для тих, хто страждає від помірного або сильного болю, але серед усіх ми приділяємо особливу увагу хворим на рак і СНІД через величезну потребу в паліативній допомозі серед цих груп, а також людям похилого віку та дітям, для яких паліативна допомога вважається другорядною.

Метою написання цієї статті $є$ висвітлення прав людини у системі паліативної допомоги в Україні.

Основна частина. Питання розвитку хоспісної та паліативної допомоги в Україні привертають до себе все більше уваги останнім часом. У 2010 р. було створено Всеукраїнську громадську організацію «Українська ліга сприяння розвитку паліативної та хоспісної допомоги». У 2011 р. паліативну допомогу було включено як окремий вид медичної допомоги шляхом внесення змін до Закону України «Основи законодавства України про охорону здоров'я». 32015 р. започатковано видання міжнародного науково-практичного журналу «Реабілітація та паліативна медицина».

Але здебільшого цей напрям здобув висвітлення у контексті медико-соціального забезпечення та адміністративно-правового супроводу. Водночас цивільно-правовий зріз проблеми не знайшов свого адекватного дослідження у вітчизняній правовій думці, що негативно відображається на формуванні нового для України виду медичної допомоги. Адже повнолітні паліативні хворі не тільки потребують уваги та допомоги, вони є фізичними особами, які володіють всіма суб'єктивними цивільними правами, передбаченими у ЦК України та спеціальному законодавстві.

Отже, на часі акцентування уваги на необхідності дослідження особливостей правового регулювання відносин із надання паліативної медичної допомоги методом приватного права.
Саме тому предметом статті обрано особливості здійснення особистих прав на медичну інформацію та вибір методів лікування суб'єктами правовідносин із надання паліативної допомоги.

Права паліативних хворих походять від прав, закріплених у Конвенції про захист прав людини і основоположних свобод (1950р.). Зокрема, це: право на життя (ст. 2), заборона катувань (ст. 3) та право на повагу до приватного і сімейного життя (ст. 8).

Ці права однаково належать як здоровим, так і хворим, отже, кожен має право або дозволити медичне втручання у свій організм, або відмовитися від такого. У європейській традиції будь-який захід, що здійснюється проти волі пацієнта, вважається дією, що спричинила тілесне ушкодження. (Проте принцип особистої автономії, як правило, не трактується в аспекті права на активні втручання від інших людей, то ж лікуючий лікар не матиме обов'язку вчинити захід, який не $\in$ медично доцільним). Такий підхід походить від європейських етико-правових цінностей та традиційно відстоюється та рекомендується у документах Ради Європи.

Оскільки Україна тільки стає на цей цивілізаційний шлях, варто врахувати напрацьовані європейською спільнотою принципи та правові конструкції, які можна застосувати з урахуванням національних особливостей у вітчизняне правове поле.

Вихідним принципом, який є наріжним та проходить червоною стрічкою через усі відповідні документи Ради Європи, є принцип особистої автономії та самовизначення паліативного хворого. Як визначено у ключовому документі з цього питання - Резолюції ПАРЄ № 1649 (2009 р.) «Паліативна допомога: модель інноваційної медичної та соціальної політики», система паліативної допомоги повинна забезпечувати можливості для самовизначення людині, яка має серйозне захворювання, страждає від перманентного болю або перебуває у стані відчаю. Це означає, що автономія $\epsilon$ обов'язковою вимогою для визначення суб'єктивної формули здоров'я та включає свободу самостійно вирішувати, як справлятися з хворобою і смертю [3].

Так, згідно з європейськими правовими стандартами стосовно надання паліативної та хоспісної допомоги право на автономію та самовизначення розпадається на три аспекти та, відповідно, реалізується шляхом впровадження відповідних правових засобів: право на отримання повної медичної інформації; право на вибір методів лікування та догляду; право 
на складання та врахування документів із попередніх розпоряджень пацієнта.

Ці три аспекти є складовими міжнародно-правових стандартів щодо медико-соціального обслуговування паліативних пацієнтів та послідовно викладені у документах Ради Європи, починаючи з 1976 р.

У Рекомендації щодо прав хворого і помираючого (1976 р.) ПАРЄ констатує, що права на особисту гідність, цілісність та інформацію мають бути чітко визначені та гарантовані кожній людині, та рекомендує, що лікарі мають, в першу чергу, дізнаватися про волю хворого щодо лікування, яке пропонують [4].

У Рекомендації 1418 (1999р.) щодо захисту прав людини і гідності невиліковно хворих і помираючих серед найсуттєвіших загроз, які існують на сучасному етапі, для дотримання прав паліативних хворих названо «штучне продовження процесу вмирання або використання непропорційних заходів медичного характеру без згоди пацієнта» [5].

У зв'язку з цим, ПАРє закликає уряди держав-членів встановити етичні правила поводження з особами, які наближаються до кінця життя, та на цій основі визначити медичні та юридичні керівні принципи та норми національного законодавства у цій сфері.

\section{у сфері паліативної допомоги пацієнти мають право:}

- на зменшення болю;

- на допомогу в подоланні фізичних і психологічних страждань;

- отримувати необхідні лікарські засоби у сфері паліативної допомоги;

- отримувати духовну та моральну підтримку;

- на допомогу, спрямовану на підтримку сім'і;

- на допомогу, яку надають кваліфіковані спеціалісти, котрі мають підготовку в сфері паліативної допомоги;

- отримувати допомогу вдома, помираючи, i, за бажанням, помирати вдома;

- на лікування хвороби і відмову від розпочатого лікування або відмову від запропонованих методів лікування;

- отримувати медичну інформацію, у тому числі про діагноз, прогнози і здійснювані медичні втручання;

- визначати довірену особу, яка прийматиме рішення щодо ії здоров'я та надання медичної допомоги;

- на рівний доступ до медичної допомоги та надання послуг (у тому числі недискримінацію при отриманні якісної та своєчасної паліативної допомоги незалежно від віку, статі, соціально-економічного ста- тусу, національності, життєвого прогнозу або шляхів інфікування);

- на систему підтримки, щоб допомогти пацієнтам жити як можна більш активно до самої смерті;

- отримувати юридичні послуги з питань нерухомості та іншого майна, опіки над дітьми, оформлення довіреності або інші правові послуги, необхідні для пацієнта;

- на систему підтримки, щоб допомогти сім'ї протягом хвороби пацієнта і в час тяжкої втрати;

- отримувати послуги з метою задоволення потреб пацієнтів і їхніх сімей, у тому числі консультування після тяжкої втрати.

Підхід, що ґрунтується на правах людини, спрямований на те, щоб права людини керували відносинами між особами, які наділені правами (окремі особи та групи, які мають певні права), та зобов'язаними особами (особи, які зобов'язані забезпечувати здійснення цих прав, наприклад держава). Програмування вимагає оцінки й аналізу з метою визначити правові вимоги осіб, які наділені правами, і відповідні зобов'язання з прав людини, носіїв обов'язків, а також негайні, основні та структурні причини недотримання реалізації цих прав.

Підхід, що ґрунтується на правах людини, працює в напрямі зміцнення потенціалу осіб, які наділені правом, для того, щоб вони могли пред'являти вимоги носіям обов'язків щодо їхнього забезпечення, як це визначено в міжнародних стандартах у сфері прав людини.

Підхід, що ґрунтується на правах людини, також фокусується на населенні, яке було маргіналізоване, позбавлене привілеїв або виключене з певних кіл, аби гарантувати їм можливість мати права та бути носіями обов'язків і надати всім групам населення можливість брати участь у процесі та результатах.

Висновки. У 2011 р. у медико-правовому просторі України відбулася соціально значуща подія - паліативну допомогу було легалізовано. У ст. 8 паліативну допомогу було додано до переліку видів медичної допомоги, які кожен громадянин має право отримати безоплатно у державних та комунальних закладах охорони здоров'я.

Також згідно із Законом України від 07.07.2011 р. № 3611-VI у тексті профільного закону «Основи законодавства України про охорону здоров'я» з'явилася стаття 35-4 «Паліативна допомога», в якій зазначено: «На останніх стадіях перебігу невиліковних захворювань пацієнтам надається паліативна допомога, яка 
включає комплекс заходів, спрямованих на полегшення фізичних та емоційних страждань пацієнтів, а також надання психосоціальної і моральної підтримки членам їх сімей».

Паліативна допомога в Україні набула законодавчого визначення та державного визнання. Це значний крок у гуманізації суспільства. Тепер на часі кропітка робота з формування правового механізму регулювання цієї галузі медико-соціальної допомоги, зокрема цивільно-правових засобів здійснення прав паліативних хворих на засадах визнаних міжнародноправових стандартів.

\section{СПИСОК ЛІТЕРАТУРИ}

1. Рішення Європейського суду з прав людини від 10 червня 2010 р. у справі «Релігійна община Свідків Єгови м. Москва проти Російської Федерації» [Електронний ресурс]. - Режим доступу : http://www.portal-credo. ru/site/?act=lib\&id=2743.

2. Генеральна Асамблея ООН. Доповідь Спеціального доповідача з питань охорони здоров'я, A/65/255 (6 серпня 2010 р.).

3. Паллиативное лечение: образец инновационного подхода к здравоохранению и социальной политике : Резолюция Парламентской Ассамблеи Совета Европы от 28.01.2009 г. № 1649 [Электронный ресурс]. Режим доступа : http://www.coe.int/T/r/Parliamentary_ Assembly/\%5BRussian_documents\%5D/\%5B2009\%5D/\%5 bJan2009\%5d/Res1649_rus.asp.
Основне правило європейського приватного права стосовно того, що нікого не можна піддавати медичному втручанню без його згоди, на практиці означає, що людина як пацієнт має безумовне право на інформований вибір методів лікування і на відмову від втручання, яке з суб'єктивної точки зору є неприйнятним, а медичні працівники повинні поважати цей вибір.

Зобов'язання держави поважати і захищати гідність невиліковно хворої людини походить від юридичного визнання недоторканості людської гідності на всіх етапах її життя. У такий спосіб захист здоров'я, прав та гідності паліативних хворих залишається найважливішим завданням національної правової системи.

4. Про права хворих і вмираючих : Рекомендація ПАРЄ № 779 (1976р.) [Електронний ресурс]. - Режим доступу : http://assembly.coe.int/Main.asp?link=/Documents/ AdoptedText/ta76/EREC779.htm\#1.

5. Protection of the human rights and dignity of the terminally ill and the dying. Recommendation. Doc: 1418 [Електронний ресурс]. - Режим доступу: http://assembly. coe.int/ASP/Doc/XrefATDetailsE.asp?FileID=16722. 6. Про внесення змін до Основ законодавства України про охорону здоров'я щодо вдосконалення надання медичної допомоги : Закон України // Відомості Верховної Ради України. - 2012. - № 14. - Ст. 86. 